\title{
The germination niche of coastal dune species as related to their occurrence along a sea-inland gradient
}

\section{Silvia Del Vecchio ${ }^{1}$ (D) | Edy Fantinato ${ }^{1}$ (D) | Mauro Roscini ${ }^{1}$ (D) | Alicia T. R. Acosta ${ }^{2}$ (D) | Gianluigi Bacchetta ${ }^{3}$ (D) | Gabriella Buffa ${ }^{1}$ (D)}

${ }^{1}$ Department of Environmental Sciences, Informatics and Statistics, Ca' Foscari University of Venice, Venice, Italy

${ }^{2}$ Department of Sciences, University of Rome 3, Rome, Italy

${ }^{3}$ Sardinian Germplasm Bank (BG-SAR), Hortus Botanicus Karalitanus (HBK),

University of Cagliari, Cagliari, Italy

\section{Correspondence}

Silvia Del Vecchio, Department of Environmental Sciences, Informatics and Statistics, Ca' Foscari University of Venice, Via Torino 155, 30172 Venice, Italy Email: silvia.delvecchio@unive.it

Co-ordinating Editor: Judit Sonkoly

This article is a part of the Special Feature Plant dispersal and establishment as drivers of vegetation dynamics and resilience, edited by Péter Török, James M. Bullock, Borja Jiménez-Alfaro and Judit Sonkoly.

\begin{abstract}
Aims: The early phases in the life cycle of a plant are the bottleneck for successful species establishment thereby affecting population dynamics and distribution. In coastal environments, the spatial pattern of plant communities (i.e. vegetation zonation) follows the ecological gradient of abiotic stress changing with the distance from the sea. This pattern has been mainly explained based on the adaptation and tolerance to the abiotic stress of adult plants. However, the adult niche may considerably differ from the germination niche of a plant species. The aim of this work was to investigate to what extent abiotic factors (specifically salinity, temperature, nitrogen and their interactions) constrain seed germination along the sea-inland gradient.

Location: Latium coast (Central Italy).

Methods: Germination tests were performed on seeds of focal species of three different plant communities which establish at increasing distances from the coastline: Cakile maritima subsp. maritima, Elymus farctus, Crucianella maritima. We tested increasing concentrations of $\mathrm{NaCl}$ (one of the main abiotic factors which decrease across the sea-inland gradient), and their interactions with temperature and $\mathrm{KNO}_{3}$, to consider other factors which drive germination processes.

Results: The tolerance to salinity significantly decreased in relation to the position of species along the coastal zonation. Crucianella maritima was shown to be the least tolerant species, having a decrease in germination $>80 \%$ across all conditions. $\mathrm{KNO}_{3}$ significantly (although slightly) increased the germination percentage in Cakile maritima subsp. maritima and Elymus farctus. When combined with $\mathrm{NaCl}, \mathrm{KNO}_{3}$ alleviated the negative effects of salinity only in Cakile maritima subsp. maritima.

Conclusions: The germination responses to the interaction among the tested factors suggest that the germination niche may explain vegetation zonation filtering species at their early stages. Quantifying environmental niches in different phases of the life cycle of plants may provide important insights into community assembly processes.
\end{abstract}

\section{KEYWORDS}

adaptation, environmental gradient, germination, Mediterranean basin, nitrogen, psammophilous vegetation, salinity, temperature 


\section{1 | INTRODUCTION}

Post-dispersal processes as germination and seedling development are the bottleneck for successful species establishment, and thus are key determinants of species distribution patterns and population dynamics (Grubb, 1977; Donohue et al., 2010; Huang et al., 2010; Poschlod et al., 2013; Cogoni et al., 2019). At the same time, such early stages of the plant's life cycle are strongly affected by environmental factors and are recognised as the most vulnerable phases for plant establishment (Walck et al., 2011; Parmesan \& Hanley, 2015; Slaviero et al., 2016). However, patterns of species coexistence or spatial distribution in relation to environmental factors have been mainly explained taking into consideration adult plants, while other stages have often been overlooked, despite their important role in plant establishment (Fantinato et al., 2018). Specifically, the regeneration niche (Grubb, 1977; Poorter, 2007), i.e. the set of environmental requirements necessary for germination and establishment of a plant species, may differ from the adult niche, and the analysis of the responses of early phases to varying environmental conditions may significantly contribute to elucidating ecological processes related to vegetation dynamics (Jiménez-Alfaro, et al., 2016; Saatkamp et al., 2019).

In coastal dunes, factors such as salinity, soil temperature and moisture, nutrient availability, wind intensity, and sand burial change sharply from the coastline inland, leading to the formation of vegetation belts arranged parallel to the coastline, which can be identified by the species turnover (i.e. "vegetation zonation"; Doing, 1985; Torca et al., 2019). The drift line, which is exposed to marine influence more than the other zones, is characterised by intense wind and salt spray (Martínez \& Psuty, 2004; Fenu et al., 2013; McLachlan $\&$ Defeo, 2017). As a consequence of sparse vegetation cover, the soil is exposed to intense solar radiation, and can reach high temperature values (up to $60^{\circ} \mathrm{C}$ at the surface; Martínez \& Psuty, 2004; Maun, 2009). The marine influence, e.g. wind intensity and salinity, gradually decreases inland, and makes semi-fixed and fixed dunes less limiting for species survival. Soil temperature is often lower on the dunes than in the drift line, because of the shade provided by the higher vegetation cover (about $10^{\circ} \mathrm{C}$ lower than in bare soil; Martínez \& Psuty, 2004; Rajaniemi \& Barrett, 2018). Nutrients, which are mostly represented by nitrates, are generally scarce, except for the drift line and the fixed dune, where they are more abundant than in the shifting dunes (Martínez \& Psuty, 2004; McLachlan $\&$ Defeo, 2017). This environmental gradient is the main driver of the species turnover from the sea to inland, leading to the formation of vegetation belts arranged parallel to the coastline (i.e. "vegetation zonation"; Doing, 1985; Torca et al., 2019).

The vegetation zonation represents a striking peculiarity of coastal environments worldwide, and features such as the number of belts, their connectivity, spatial extent, and species composition are regarded as useful indicators of the conservation status of coastal systems, since their modification indicates possible alteration of the system functionality (Buffa et al., 2005; Carboni et al., 2009; Gigante et al., 2016; Fenu et al., 2017; Pinna et al., 2019; Del
Vecchio et al., 2018). The turnover of species along the sea-inland gradient has been traditionally explained by adaptations and tolerance of adult plants to abiotic factors (Fenu et al., 2013; Bazzichetto et al., 2016; Torca et al., 2019). In fact, research showed that environmental factors such as salinity and soil temperature select the most tolerant species to establish closer to the sea (e.g. Cakile maritima, Salsola kali), while the species less adapted to withstand abiotic stress are constrained to grow in the inner, more protected, zones (e.g. dwarf shrubs of semi-fixed dunes; Silan et al., 2017; Del Vecchio et al., 2018; Fantinato et al., 2018).

However, there may be no match between adults and the germination phase in terms of their tolerance to abiotic factors. For example, while adult plants may tolerate high salt concentration as well as high temperature, in some cases they proved to be very salt-sensitive during the germination phase and seedling development (Gul et al., 2013; Yuan et al., 2019), especially at high temperature (El-Keblawy \& Al-Shamsi, 2008; Manzoor et al., 2017; Santo et al., 2017). Although the treatment effects vary across species, literature demonstrated that $\mathrm{NaCl}$ concentrations higher than $250 \mathrm{mM}$ can completely suppress germination (Del Vecchio et al., 2012; Delgado Fernández et al., 2016; Santo et al., 2017; Del Vecchio, Porceddu et al., 2019), while long exposure time can have detrimental effects, leading to seed mortality (Saeed et al., 2011; Santo et al., 2014; Del Vecchio, Porceddu et al., 2018).

Temperature is a regulator of germination timing, and its role is particularly important in systems with a marked seasonality, such as those of the Mediterranean or Temperate regions, where temperature fluctuations within the year might be stronger than among different years (Baskin \& Baskin, 2014). During the transition from seed to seedling, species are often quite sensitive to extreme temperatures and thermal cues regulate germination to occur during the best period for seedling survival (Baskin \& Baskin, 2014). However, adult species may tolerate a different temperature range, using morphological and physiological adaptations to withstand freezing or overheating (Larcher, 2003).

Similarly to salinity and temperature, other factors such as nutrient availability, which also vary along the sea-inland gradient, are known to significantly influence the germination process (Hilhorst \& Karssen, 2000) and may contribute to the vegetation zonation selecting species based on their requirements during germination. It has been shown that $\mathrm{K}$ and $\mathrm{N}$ compounds can affect germination (Atia et al., 2009; Duermeyer et al., 2018). $\mathrm{KNO}_{3}$ has been recognised as a germination promoter (Pons, 1989), increasing both seed germination percentage and germination speed in several species (Duermeyer et al., 2018). Effects on germination can also derive from the interaction of $\mathrm{KNO}_{3}$ and $\mathrm{NaCl}$, although with contrasting patterns. Specifically, $\mathrm{KNO}_{3}$ has been proven to alleviate salt-induced stress in several species (Neid \& Biesboer, 2005; Atia et al., 2009; Zehra et al., 2013) including Elymus farctus (El-Katony et al., 2015). Conversely, $\mathrm{KNO}_{3}$ could not alleviate the effect of salinity in Silene mollissima aggregate (Murru et al., 2015) and in Vicia faba (Abd El-Baki et al., 2018). However, unlike salinity and temperature, which in general decrease linearly from the sea 
inland, nutrient levels have a more complex distribution pattern with an uneven, bimodal trend, being at higher concentrations in the fixed dune and along the drift line, mainly due to higher litter deposition, and decomposition of seagrass wrack deposits, respectively (McLachlan \& Defeo, 2017).

Temperature, salinity and nitrogen have often been investigated in seed ecology research (e.g. Gul et al., 2013; Baskin \& Baskin, 2014; Duermeyer et al., 2018); however, only seldom research considered their interactions in relation to coastal zonation. In this context, the aim of this work was to investigate whether there is a relationship between seed germination responses to abiotic factors and the adult spatial distribution pattern along the coastal gradient. To this end, we selected three species typical of different belts of the coastal zonation (Cakile maritima subsp. maritima, Elymus farctus, Crucianella maritima) and set out an experiment to analyse their germination niche with respect to salinity, also considering its interactions with temperature and nitrogen. We hypothesise that, irrespective of the adult niche, germination requirements have a role in shaping vegetation patterns and the distribution of species along the coastal environmental gradient by selecting halo-nitrophilous species near the coastline (Cakile maritima subsp. maritima), salt-tolerant species beyond the first belt of vegetation (Elymus farctus), and salt-sensitive species more inland (Crucianella maritima).

\section{2 | METHODS}

\subsection{Study site}

Seeds of the three species were collected in Central Italy, along the Latium coast (between Torre Flavia, latitude and longitude, DD: 41.96171366, 12.04590248, and Passoscuro, 41.912327, 12.145901). The area is characterised by a Mediterranean Pluviseasonal Oceanic (MPO) bioclimate, with hot and dry summer and mild rainy winter (Rivas-Martínez et al., 2004). The changes in salinity, soil temperature, nutrients, wind intensity and sand burial, and the position of the target species along the vegetation zonation are represented in Figure 1.

\section{2 | Seed collection}

We selected focal species (namely the key species pivotal to habitat structure and function; e.g. Benson, 2006; Lindgaard \& Henriksen, 2011; Keith et al., 2013) of three different plant communities that thrive at increasing distance from the coastline, subjected to progressively less harsh environmental condition: (i) Cakile maritima subsp. maritima (hereafter referred to as Cakile), an annual species of the drift line, i.e. the vegetation zone closest to the coastline; (ii) Elymus farctus (hereafter referred to as Elymus), a perennial herbaceous of the embryonic shifting dunes; (iii) Crucianella maritima (hereafter referred to as Crucianella), a dwarf shrub of Mediterranean semi-fixed dunes (Acosta et al., 2003). Species nomenclature follows Bartolucci et al. (2018).

Seeds were collected from 80 randomly selected individuals, at the time of natural dispersal (in mid-July 2017 for all the species) and sent to the Sardinian Germplasm Bank (BG-SAR) of the University of Cagliari (Italy), where they were manually cleaned. To enable equal conditions among seeds, they were after-ripened at room temperature $\left(20^{\circ} \mathrm{C}\right.$ and $40 \%$ relative humidity $\left.[\mathrm{RH}]\right)$ for 40 days, dehydrated $\left(15^{\circ} \mathrm{C}\right.$ and $\left.15 \% \mathrm{RH}\right)$ and stored at $5^{\circ} \mathrm{C}$ until the experiment started, for a total of 90 days.

\section{3 | Germination tests}

Four replicates of 20 seeds each were used for each test. Seed was sown in Petri dishes on 1\% water agar, and incubated in growth chambers (Sanyo MLR-351, Sanyo Electric Co., Ltd, Wakehurst Place, UK). We selected a range of temperature that, according to the literature (Debez et al., 2004; Del Vecchio et al., 2012; El-Katony et al., 2015), allowed a good germination percentage (higher than 50\%) for the target species and that was representative of the seasons of the study area. Monthly temperature values, averaged for the period 2004-2017, were retrieved from http://www.arpalazio.gov. it/. Therefore, seeds were exposed to $20^{\circ} \mathrm{C}$, which corresponded to the average temperature in late spring (May-June) and early autumn (September-October), and to $25^{\circ} \mathrm{C}$, which corresponded to the average temperature in summer (July-August; Del Vecchio, Porceddu

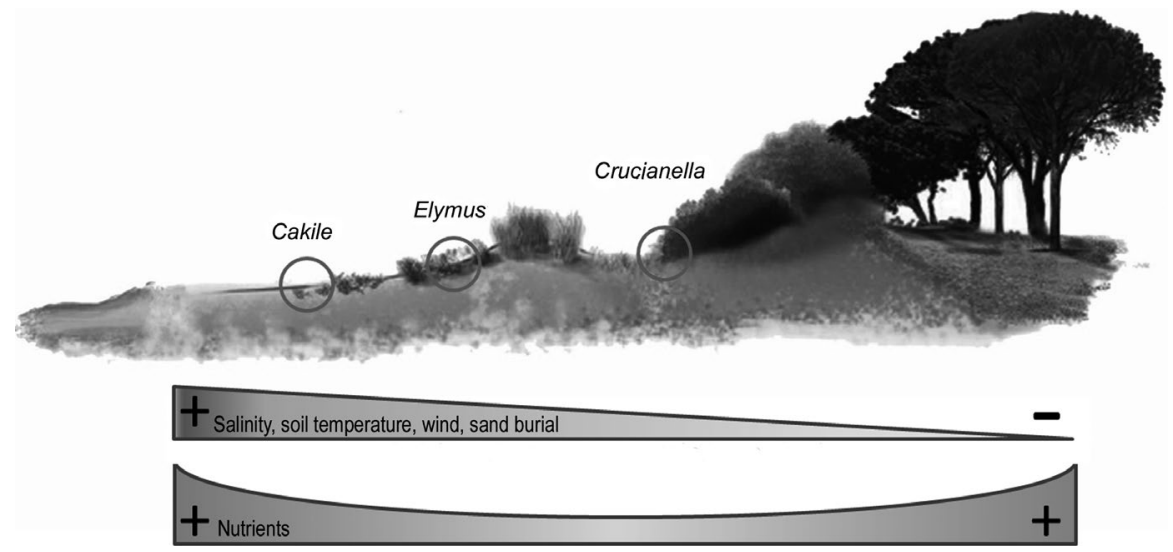

FIGURE 1 Scheme of the vegetation zonation in relation to the main environmental factors along the seainland gradient. The target species of this work, Cakile maritima subsp. maritima, Elymus farctus, and Crucianella maritima, occupy different belts, at increasing distances of the coastline (modified from Acosta and Ercole 2015) 
et al., 2019). Following previous studies, Cakile and Crucianella were incubated in darkness (Debez et al., 2004; Del Vecchio et al., 2012), achieved by wrapping the dishes in two layers of aluminium foil, while Elymus was incubated in a 12/12 light/dark photoperiod (Royal Botanic Gardens Kew, 2008).

To test the effect of salinity, nitrogen and their interaction, seeds were incubated at the same temperature and light regimes on $1 \%$ water agar, with different solutions. To test the effects of different salt concentrations, we used $\mathrm{NaCl}$ at 125 and $250 \mathrm{mM}$. These concentrations were selected on the basis of a geometric series spaced by a factor of 0.5 (OECD, 2006). We started from $\mathrm{NaCl}$ seawater concentration $(500 \mathrm{mM})$ and considered as testing conditions its dilution at 50\% (250 mM) and 25\% (125 mM). We excluded to test $\mathrm{NaCl} 500 \mathrm{mM}$ because it has already been demonstrated that it suppressed the germination for the target species (Debez et al., 2004; Del Vecchio et al., 2012; El-Katony et al., 2015). We also excluded $\mathrm{NaCl}$ concentrations that represented seawater dilution beyond $25 \%$ ( $12.5 \%$, corresponding to a $\mathrm{NaCl}$ concentration of $62.5 \mathrm{mM}$ ) because for several species germination was not different from that in freshwater, while differences have been observed at $\mathrm{NaCl}$ higher than $100 \mathrm{mM}$ (including Cakile maritima and Elymus farctus; Debez et al., 2004; Guja et al., 2010; El-Katony et al., 2015). To test the effect of nitrogen, we used $\mathrm{KNO}_{3}(10 \mathrm{mM})$ as nitrogen source. Despite both nitrates and ammonium being present in the field (Martínez \& Psuty, 2004; Maun, 2009), nitrates are often more abundant than ammonium (Alpert \& Mooney, 1996;
Kachi \& Hirose, 1983; Bonanomi et al., 2012), especially at the alkaline $\mathrm{pH}$ observed in coastal dunes along the Tyrrhenian coast (Kooijman \& Basse, 2002; Fenu et al., 2012; Ruocco et al., 2014; USDA, 2014). The selected concentration falls within the range of possible substrate nitrogen contents measured in the field (Pizzo, 2012). Moreover, $\mathrm{KNO}_{3}$ at the concentration of $10 \mathrm{mM}$ was widely used, and proved to have positive effects on seed germination, and in alleviating salinity stress (Atia et al., 2009; Duermeyer et al., 2018). To test the interaction of salinity and nitrogen we used a mixed solution with $\mathrm{NaCl} 125 \mathrm{mM}$ and $\mathrm{KNO}_{3} 10 \mathrm{mM}$. We used only the lowest concentration of $\mathrm{NaCl}$ because from preliminary tests it proved to significantly reduce or suppress the germination of the target species.

For all the tests, seeds were scored only once, at the end of the experiment after 75 days from sowing. At the end of the test, non-germinated seeds were cut (Ooi et al., 2004; FAO, 2014), observed under the stereoscope and classified as viable, died or empty, and the final number of germinated seeds was calculated based on the total number of filled seeds.

\section{4 | Data analyses}

Germination of the three species at different temperatures was compared by two-way PERMANOVA with 9,999 randomisations (Past software; Hammer et al., 2001; Anderson, 2014) followed by a
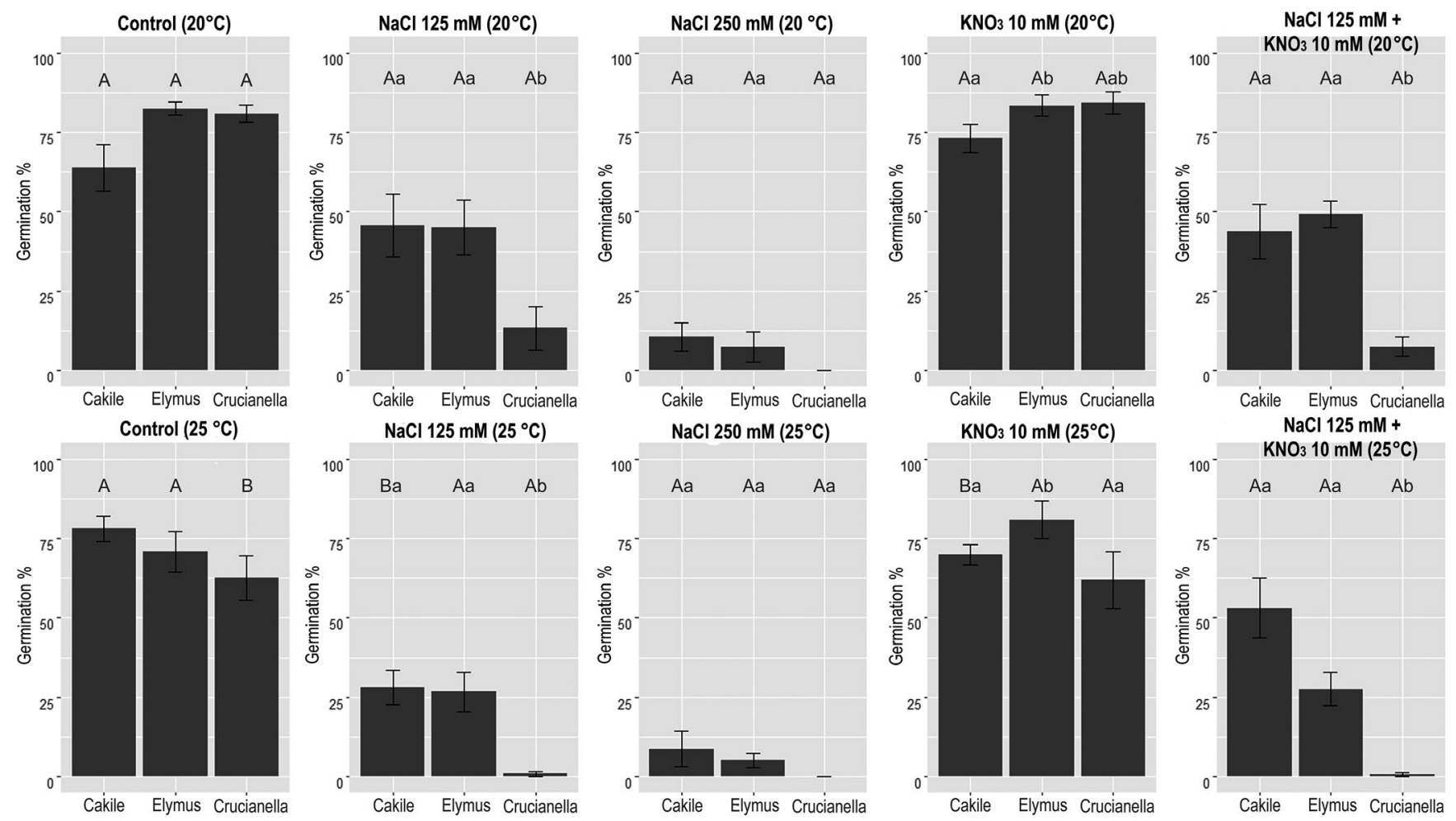

FIGURE 2 Germination percentage (mean $\pm S E$ ) for each species, at each condition. Bars with different letters are significantly different in a post-hoc Fisher test. Lowercase letters indicate differences across species, at the same condition. Capital letters indicate differences within species across temperature. Significant differences between the decrease in germination at $\mathrm{NaCl} 125 \mathrm{mM}$ and the combined solution of $\mathrm{NaCl}$ and $\mathrm{KNO}_{3}$ are indicated only in the text 
TAB LE 1 Variation in germination percentage (mean $\pm S D$ ) for each species at each condition compared to control (PERMANOVA and post-hoc Fisher test). Negative values indicate decrease, while positive values indicate increase in germination percentage compared to seed sown in agar only, at $20^{\circ} \mathrm{C}$ and $25^{\circ} \mathrm{C}$

\begin{tabular}{|c|c|c|c|c|c|c|c|c|c|c|c|c|}
\hline \multirow[b]{3}{*}{ Temperature $\left({ }^{\circ} \mathrm{C}\right)$} & \multicolumn{3}{|c|}{$\mathrm{NaCl} 125 \mathrm{mM}$} & \multicolumn{3}{|c|}{$\mathrm{NaCl} 250 \mathrm{mM}$} & \multicolumn{3}{|c|}{$\mathrm{KNO}_{3} 10 \mathrm{mM}$} & \multicolumn{3}{|c|}{$\begin{array}{l}\mathrm{NaCl} 125 \mathrm{mM}+\mathrm{KNO}_{3} \\
10 \mathrm{mM}\end{array}$} \\
\hline & \multicolumn{3}{|l|}{20} & \multicolumn{3}{|l|}{20} & \multicolumn{3}{|l|}{20} & \multicolumn{3}{|l|}{20} \\
\hline & Mean & & $S D$ & Mean & & $S D$ & Mean & & $S D$ & Mean & & $S D$ \\
\hline Cakile & -36.3 & \pm & 33.5 & -85.4 & \pm & 17.2 & 33.3 & \pm & 78.8 & -30.8 & \pm & 33.2 \\
\hline Crucianella & \multicolumn{3}{|l|}{25} & \multicolumn{3}{|l|}{25} & \multicolumn{3}{|l|}{25} & \multicolumn{3}{|l|}{25} \\
\hline Temperature $\left({ }^{\circ} \mathrm{C}\right)$ & \multicolumn{2}{|l|}{ Mean } & $S D$ & \multicolumn{2}{|l|}{ Mean } & $S D$ & \multicolumn{2}{|l|}{ Mean } & $S D$ & \multicolumn{2}{|l|}{ Mean } & $S D$ \\
\hline Cakile & -64.3 & \pm & 21.3 & -89.1 & \pm & 19.4 & -8.4 & \pm & 18.5 & -33.1 & \pm & 28.1 \\
\hline
\end{tabular}

post-hoc Fisher test, using germination percentage as response variable, and temperature and species as grouping variables.

To compare germination responses to salinity, nitrogen, the combined solution, and their interaction with temperature among the species, we focused on the variation in germination with respect to germination in agar only (control). At each temperature, we calculated the percentage of increase or decrease in germination under $\mathrm{NaCl}, \mathrm{KNO}_{3}$, and their combination, with respect to the control. This allowed measuring the intensity of the response of the species to the same factors, independently of their absolute germination values. We assumed that species that show intense variation to a factor are more sensitive than species that show a low variation.

To analyse if the variation in germination differed among species, we used one-way PERMANOVA, with 9,999 randomisations. As grouping variable, we used species at each condition of temperature and tested solution. Differences among species at the same condition and within species over temperature were assessed by a posthoc Fisher test.

\section{3 | RESULTS}

All the species had a germination percentage higher than $50 \%$ at all tested temperatures (Figure 2, "Control" bar plots). Germination percentages averaged by temperature were $70.9 \pm 17.8 \%$ for Cakile, $76.7 \pm 12.9 \%$ for Elymus, and $71.7 \pm 15.7 \%$ for Crucianella. However, species differed in their response to changes in temperature (two-way PERMANOVA test; $p<0.001$ ). Specifically, Cakile and Crucianella showed opposite trends: Cakile had a higher germination percentage at high temperature, although the increase was not significant $\left(63.8 \pm 20.8 \%\right.$ at $20^{\circ} \mathrm{C}$ vs $78.1 \pm 11.3 \%$ at $25^{\circ} \mathrm{C}$; posthoc Fisher test, $p=0.05)$, while Crucianella showed higher values at moderate temperature $\left(80.8 \pm 6.6 \%\right.$ at $20^{\circ} \mathrm{C}$ vs $62.5 \pm 17.2 \%$ at $25^{\circ} \mathrm{C}$; post-hoc Fisher test, $p=0.03$ ). Elymus showed a lower germination percentage at $25^{\circ} \mathrm{C}$, but the difference was not significant $\left(82.5 \pm 5.2 \%\right.$ at $20^{\circ} \mathrm{C}$ vs $70.8 \pm 15.9 \%$ at $25^{\circ} \mathrm{C}$; post-hoc Fisher test, $p=0.17)$.

Regarding salinity and nitrogen, one-way PERMANOVA revealed significant differences among species at the same condition and within species between temperatures $(F=15.01 ; p=0.0001)$. Overall, salinity had a detrimental effect on the germination percentage and at $\mathrm{NaCl} 250 \mathrm{mM}$ : germination was suppressed for all the species, producing a decrease in the range of $85 \%-100 \%$ at each temperature (Table 1; Figure 2).

At $\mathrm{NaCl} 125 \mathrm{mM}$, Cakile appeared to be the most salt-tolerant species, showing a decrease in germination of about 35-65\% across temperature (Table 1; Figure 2). Elymus showed a decrease in germination comparable to Cakile, although a little higher (in the range of 45-65\%). In both species, increasing temperature exacerbated the negative effect of salinity, although the difference was significant only for Cakile. Crucianella exhibited the lowest tolerance to salinity, consistently showing a decrease in germination higher than $80 \%$ at all tested temperatures.

Germination had a narrow range of variation under $\mathrm{KNO}_{3}$. It showed a fluctuating pattern, increasing or decreasing on average by less than $10 \%$ compared to germination in the control. The highest effects were an increased germination in Cakile at $20^{\circ} \mathrm{C}$, which was $33 \%$ higher compared to control, and in Elymus at $25^{\circ} \mathrm{C}$ (about $20 \%$ higher than control; Table 1; Figure 2).

The combined solution of $\mathrm{NaCl}$ and $\mathrm{KNO}_{3}$ had a slight effect on the germination percentage, with the only significant positive effect being observed in Cakile at its optimal germination temperature (post-hoc Fisher test; $p=0.01$ between decrease in germination under $\mathrm{NaCl} 125 \mathrm{mM}$ and the combined solution, at $25^{\circ} \mathrm{C}$ ). In Elymus and Crucianella, $\mathrm{KNO}_{3}$ did not significantly alleviate the effect of salinity at any of the tested temperatures. 


\section{4 | DISCUSSION}

Our results showed that the focal species, which are typical of successive vegetation belts of Mediterranean sandy coastal systems, have different germination responses to temperature, salinity, nitrogen and their interaction. Although the distribution of species in the field results from the combination of several factors (e.g. abiotic and biotic interactions), our results suggest that the germination niche of the focal species may contribute to determine their distribution in coastal dunes, precluding salt and high temperature-sensitive species to germinate near the coastline.

\subsection{Effect of temperature}

Although we tested a narrow range of temperatures, it was possible to observe a different response in the target species, with a decreasing tolerance according to their typical position along the sea-inland gradient. Cakile, a characteristic species of the drift line, showed adaptation to high temperature, with decreasing germination percentage at the lowest tested value. Elymus, characteristic of the embryo dune, exhibited a wider niche, being able to germinate at both temperatures at comparable percentages. Conversely, Crucianella, narrowly restricted to semi-fixed dune grasslands, most successfully germinated at the lower temperature tested. These results are in line with those of Rajaniemi and Barrett (2018), who found a similar trend, with species able to germinate at high temperature mostly located near to the coastline, and species with lower tolerance establishing in the inner zones. Although our results are based on laboratory tests, and on three species representative of different vegetation belts, they suggest that an optimal temperature requirement for a maximum germination percentage could be considered in this way as an adaptive strategy (Hesp, 1991). However, previous studies which analysed coastal dune species during the adult phase reported that species of coastal grasslands of semi-fixed dunes are more thermophilic (i.e. adapted to tolerate high temperature during the adult phase) than the species of the drift line and fixed dune (Isermann, 2011; Del Vecchio et al., 2015). Therefore, we could suggest that compared to the adult phase, for the tested species the response to temperature along the sea-inland gradient has opposite trends during the germination. A higher number of species should be analysed for a more comprehensive understanding of high temperature tolerance and the possible difference between the germination and the adult phase.

Temperature has most often been used to explain temporal patterns of germination, since the highest variations occur in relation to seasons (Martínez \& Psuty, 2004; Baskin \& Baskin, 2014; Santo et al., 2019). In fact, the ability of Cakile and Elymus to germinate at high temperature may be related to their adaptation to emerge in late spring and summer, while Crucianella, which is adapted to moderate temperatures, is more likely to emerge in early spring and autumn (Davy et al., 2006; Del Vecchio et al., 2012; Baskin \& Baskin, 2014). In addition, such a seasonal pattern could also be related to the spatial distribution of species along the sea-inland gradient. Indeed, germination at higher temperatures, which in Mediterranean temperate climates coincide with the summer season, prevents the species growing close to the coastline to emerge in winter, which represents the most limiting period for the strandline, due to intense storms and excessive sand burial (Fernández-Pascual et al., 2017). On the contrary, germination in early spring and autumn, usually observed in inland species, prevents seedling to emerge in summer, which represents the most critical season due to water stress (FernándezPascual et al., 2017). Comparison of the Mediterranean systems with others, such as tropical systems or those of cold temperate regions, will be useful to explore whether and which patterns can be generalised, and which ones are more dependent on local adaptation.

\section{2 | Effect of salinity}

Our study showed that substrate salinity acts as a major selective force in seed germination for the target species. At $\mathrm{NaCl} 250 \mathrm{mM}$, germination was hindered at all tested temperatures, also in Cakile, which is commonly described as tolerant of salt spray and transient inundation by seawater (Davy et al., 2006), allowing this concentration to be defined as a threshold for germination. However, the detrimental effects of salinity were also apparent at lower concentrations, with a linearly decreasing trend in the germination percentage from Cakile to Crucianella, and the negative effect of salinity was higher at higher temperature.

Despite its linear and often marked decreasing gradient from the sea inlands, soil salinity has been assumed to play a secondary role in explaining the spatial distribution of adult plants if compared to other factors such as soil nutrient content, sand grain size, or water availability (Isermann, 2011; Fenu et al., 2013; van Puijenbroek et al., 2017). According to Maun (2009), shoreline plant species are largely unaffected by the natural levels of salt deposition. In fact, adult plants are able to withstand salt, and the selection pressure for tolerance to substrate salinity is weak (Maun, 2009; Gul et al., 2013). Therefore, given the disruptive role of salinity in the germination phase observed in our study, we suggest that in coastal species salinity is the bottleneck for successful germination and seedling establishment, contributing in this way to the species distribution patterns by acting during early stages. Near the coastline, substrate salinity should filter out those species that are not able to germinate under saline conditions, especially if coupled with high temperature.

\section{3 | Effect of nitrogen}

Although it was not possible to identify a clear trend, we observed weak responses to nitrogen for all tested species. Only Cakile and Elymus showed a slight significant increase in germination, suggesting that they may benefit from the nutrients mainly derived from decomposing wrack on the strandline. Moreover, our results demonstrate that the interaction of nutrients with temperature plays 
a more important role, compared to nutrients alone. The capacity of nutrients to improve germination as well as their capacity to alleviate salt stress becomes significant only at a species-specific temperatures.

However, previous studies showed that nutrient availability significantly enhances seedling growth rate, improving their establishment (Maun, 1994; Del Vecchio et al., 2013) by incrementing seedling biomass (Frosini et al., 2012), and counteracting the effect of sand burial (Gilbert et al., 2008). Similarly to nitrogen alone, the interaction of nitrogen and salinity also seems to be particularly important during the post-germination phase: nitrogen supply proved to alleviate the toxic effect of salinity in seedlings, enhancing the activity of antioxidant enzymes in several species (Zheng et al., 2008; Abd El-Baki et al., 2018; Ibrahim et al., 2018). Therefore, we could affirm that nutrients such as nitrogen could limit species survival in adults but seems to have a less important role in the germination of coastal species.

\section{5 | CONCLUSIONS}

Our study explored the germination responses of typical coastal dune species to temperature, salinity, nitrogen and their interactions. Our results not only confirmed trends already known for plants of different zones but also for the first time directly compared the role of salinity and nutrients, and their interaction with temperature to explain the distribution of the study species in coastal dunes. Overall, our results suggest that the germination niche contributes to determine species distribution and turnover in coastal dunes, precluding salt- and high temperature-sensitive species to germinate near the coastline. Besides this, our research highlighted the importance of considering the interaction among factors during the germination phase. Consistent with previous research, we suggest that in coastal species salinity is the bottleneck for successful establishment; however, its negative effect can be either alleviated or exacerbated depending on the interactions with temperature and nitrogen. Moreover, our study suggests that the environmental niche in coastal dune species can vary across their life cycle, confirming the pivotal importance of gathering information on each stage of a species' life cycle. Broadening our point of view can effectively contribute to elucidate species dynamics, species' spatial distribution and patterns of species assembly.

Although germination strategies revealed by laboratory tests should be compared with caution with germination in the field, our research represents a useful approach to including the germination niche in ecological studies and lays the foundation for disentangling the role of early stages of a plant's life cycle in the population dynamics and species distribution patterns.

\section{ACKNOWLEDGEMENTS}

We are grateful to Judit Sonkoly and three anonymous reviewers for their constructive comments that helped improve an earlier version of the manuscript. We also thank Marta Carboni and Irene Prisco for their help with field sampling and the team of the Sardinian Germplasm Bank to have helped with the laboratory tests.

\section{AUTHOR CONTRIBUTIONS}

SDV, GB, AA, and GB conceived the research idea; SDV collected data; SDV, with contributions from all authors, wrote the paper.

\section{DATA AVAILABILITY STATEMENT}

The datasets generated during the current study are available from the corresponding author on reasonable request.

\section{ORCID}

Silvia Del Vecchio (iD https://orcid.org/0000-0001-8458-0433 Edy Fantinato iD https://orcid.org/0000-0003-0114-4738 Mauro Roscini (iD https://orcid.org/0000-0002-9988-4701 Alicia T. R. Acosta iD https://orcid.org/0000-0001-6572-3187 Gianluigi Bacchetta iD https://orcid.org/0000-0002-1714-3978 Gabriella Buffa iD https://orcid.org/0000-0002-0862-637X

\section{REFERENCES}

Abd El-Baki, G.K., Shaddad, M.A.K., Mostafa, D., \& Rafat, A.S. (2018). The effect of seed presoaking with $\mathrm{KNO} 3$ on seed germination, proline, protein pattern, beta-amylase and mineral composition of two faba bean cultivars treated with $\mathrm{NaCl}$. Egyptian Journal of Botany, 58 , 445-461. 10.21608/ejbo.2018.3423.1166.

Acosta, A.T.R., Stanisci, A., Ercole, S., \& Blasi, C. (2003). Sandy coastal landscape of the Lazio region. Phytocoenologia, 33(4), 715-726. https://doi.org/10.1127/0340-269X/2003/0033-0715.

Acosta, A.T.R., \& Ercole, S. (Eds.) (2015). Gli habitat delle coste sabbiose italiane: ecologia e problematiche di conservazione. ISPRA, Serie Rapporti, 215/2015.

Alpert, P., \& Mooney, H.A. (1996). Resource heterogeneity generated by shrubs and topography on coastal sand dunes. Vegetatio, 122, 83-93. https://doi.org/10.1007/BF00052818.

Anderson, M.J. (2014). Permutational Multivariate Analysis of Variance (PERMANOVA), 3rd ed. Chichester: John Wiley \& Sons Ltd.

Atia, A., Debez, A., Barhoumi, Z., Smaoui, A., \& Abdelly, C. (2009). ABA, $\mathrm{GA}(3)$, and nitrate may control seed germination of Crithmum maritimum (Apiaceae) under saline conditions. Comptes Rendus Biologies, 332, 704-710. https://doi.org/10.1016/j.crvi.2009.03.009.

Bartolucci, F., Peruzzi, L., Galasso, G., Albano, A., Alessandrini, A., Ardenghi, N.M.G. et al (2018). An updated checklist of the vascular flora native to Italy. Plant Biosystems, 152(2), 179-303. https://doi. org/10.1080/11263504.2017.1419996.

Baskin, C.C., \& Baskin, J.M. (Eds.) (2014). Seeds: Ecology, Biogeography, and Evolution of Dormancy and Germination, 2nd ed. New York: Academic Press.

Bazzichetto, M., Malavasi, M., Acosta, A.T.R., \& Carranza, M.L. (2016). How does dune morphology shape coastal EC habitats occurrence? A remote sensing approach using airborne LiDAR on the Mediterranean coast. Ecological Indicators, 71, 618-626. https://doi. org/10.1016/j.ecolind.2016.07.044.

Benson, J.S. (2006). New South Wales vegetation classification and assessment: introduction - the classification, database, assessment of protected areas and threat status of plant communities. Cunninghamia, 9, 331-382. https://core.ac.uk/download/pdf/14529 063.pdf.

Bonamoni, G., Esposito, A., \& Mazzoleni, S. (2012). Plant soil feedback in herbaceous species of Mediterranean coastal dunes. Biological Letters, 49, 53-62. https://doi.org/10.2478/v10120-012-0007-2. 
Buffa, G., Mion, D., Gamper, U., Ghirelli, L., \& Sburlino, G. (2005). Valutazione della qualità e dello stato di conservazione degli ambienti litoranei: l'esempio del S.I.C. "Penisola del Cavallino: biotopi litoranei" (Venezia, NE-Italia). Fitosociologia, 42(2), 3-13. http://hdl. handle.net/10278/14006

Cogoni, D., Sulis, E., Bacchetta, G., \& Fenu, G. (2019). The unpredictable fate of the single population of a threatened narrow endemic Mediterranean plant. Biodiversity and Conservation, 28, 1799-1813. https://doi.org/10.1007/s10531-019-01757-0.

Carboni, M., Carranza, M.L., \& Acosta, A.T.R. (2009). Assessing conservation status on coastal dunes: a multiscale approach. Landscape and Urban Planning, 91(1), 17-25. https://doi.org/10.1016/j.landu rbplan.2008.11.004.

Davy, A.J., Scott, R., \& Cordazzo, C.V. (2006). Biological flora of the British Isles: Cakile maritima Scop. Journal of Ecology, 94, 695-711. 10.1111/j.1365-2745.2006.01131.x.

Debez, A., Ben Hamed, K., Grignon, C., \& Abdelly, C. (2004). Salinity effects on germination, growth, and seed production of the halophyte Cakile maritima. Plant and Soil, 262, 179-189. https://doi. org/10.1023/B:PLSO.0000037034.47247.67.

Del Vecchio, S., Mattana, E., Acosta, A.T.R., \& Bacchetta, G. (2012). Seed germination responses to varying environmental conditions and provenances in Crucianella maritima L., a threatened coastal species. Comptes Rendus Biologies, 335, 26-31. https://doi.org/10.1016/j. crvi.2011.10.004.

Del Vecchio, S., Marbà, N., Acosta, A.T.R., Vignolo, C., \& Traveset, A. (2013). Effects of Posidonia oceanica beach-cast on germination, growth and nutrient uptake of coastal dune plants. PLoS ONE, 8, e70607. https://doi.org/10.1371/journal.pone.0070607.

Del Vecchio, S., Prisco, I., Acosta, A.T.R., \& Stanisci, A. (2015). Changes in plant species composition of coastal dune habitats over a 20 -year period. AoB PLANTS, 7, 1-10. https://doi.org/10.1093/aobpla/plv01 8(plv018).

Del Vecchio, S., Fantinato, E., Janssen, J.A.M., Bioret, F., Acosta, A.T.R., Prisco, I. et al (2018). Biogeographic variability of coastal perennial grasslands at the European scale. Applied Vegetation Science, 21, 312321. https://doi.org/10.1111/avsc.12356.

Del Vecchio, S., Fantinato, E., Silan, G., \& Buffa, G. (2019). Trade-offs between sampling effort and data quality in habitat monitoring. Biodiversity and Conservation, 28, 55-73. https://doi.org/10.1007/ s10531-018-1636-5.

Del Vecchio, S., Porceddu, M., Fantinato, E., Acosta, A.T.R., Buffa, G., \& Bacchetta, G. (2018). Germination responses of Mediterranean populations of Cakile maritima to light, salinity and temperature. Folia Geobotanica, 53, 417-428. https://doi.org/10.1007/s1222 4-018-9332-5.

Delgado Fernández, I.C., Giménez Luque, E., Gómez Mercado, F., \& Pedrosa, W. (2016). Influence of temperature and salinity on the germination of Limonium tabernense Erben from Tabernas Desert (Almería, SE Spain). Flora, 218, 68-74. https://doi.org/10.1016/j. flora.2015.12.001.

Doing, H. (1985). Coastal foredune zonation and succession in various parts of the world. Vegetatio, 61, 65-75.

Donohue, K., Casas, K.K., Burghart, L., Kovach, L.K., \& Willis, C.G. (2010). Germination, post germination adaptation, and species ecological ranges. Annual Review of Ecology, Evolution and Systematics, 41, 293-319. https://doi.org/10.1146/annurev-ecols ys-102209-144715.

Duermeyer, L., Khodapanahi, E., Yan, D.W., Krapp, A., Rothstein, S.J., \& Nambara, E. (2018). Regulation of seed dormancy and germination by nitrate. Seed Science Research, 28, 150-157. https://doi.org/10.1017/ s096025851800020x.

El-Katony, T.M., Khedr, A.A., \& Soliman, N.G. (2015). Nutrients alleviate the deleterious effect of salinity on germination and early seedling growth of the psammophytic grass Elymus farctus. Botany-Botanique, 93, 559-571.

El-Keblawy, A., \& Al-Shamsi, N. (2008). Salinity, temperature and light affect seed germination of Haloxylon salicornicum, a common perennial shrub of the Arabian deserts. Seed Science and Technology, 36, 679-688. 10.15258/sst.2008.36.3.17.

Fantinato, E., Del Vecchio, S., Giovanetti, M., Acosta, A.T.R., \& Buffa, G. (2018). New insights into plants coexistence in specie-rich communities: The pollination interaction perspective. Journal of Vegetation Science, 29, 6-14. https://doi.org/10.1111/jvs.12592.

Fantinato, E., Del Vecchio, S., Silan, G., \& Buffa, G. (2018). Pollination networks along the sea-inland gradient reveal landscape patterns of keystone plant species. Scientific Reports, 8, 1-9. https://doi. org/10.1038/s41598-018-33652-z.

FAO (2014). Genebank Standards for Plant Genetic Resources for Food and Agriculture, Rev ed. Rome, Italy.

Fenu, G., Cogoni, D., Ferrara, C., Pinna, M.S., \& Bacchetta, G. (2012). Relationships between coastal sand dune properties and plant community distribution: the case of Is Arenas (Sardinia). Plant Biosystems, 146, 586-602. https://doi.org/10.1080/11263504.2012.656727.

Fenu, G., Carboni, M., Acosta, A.T.R., \& Bacchetta, G. (2013). Environmental factors influencing coastal vegetation pattern: new insights from the Mediterranean basin. Folia Geobotanica, 48, 493508. https://doi.org/10.1007/s12224-012-9141-1.

Fenu, G., Cogoni, D., Navarro, F.B., Concas, E., \& Bacchetta, G. (2017). The importance of the Cisto-Lavanduletalia coastal habitat on population persistence of the narrow endemic Dianthus morisianus (Caryophyllaceae). Plant Species Biology, 322, 156-168. 10.1111/1442-1984.12138.

Fernández-Pascual, E., Pérez-Arcoiza, A., Prieto, J.A., \& Díaz, T.E. (2017). Environmental filtering drives the shape and breadth of the seed germination niche in coastal plant communities. Annals of Botany, 119, 1169-1177. https://doi.org/10.1093/aob/mcx005.

Frosini, S., Lardicci, C., \& Balestri, E. (2012). Global change and response of coastal dune plants to the combined effects of increased sand accretion (burial) and nutrient availability. PLoS ONE, 7, e47561. https:// doi.org/10.1371/journal.pone.0047561.

Gigante, D., Attorre, F., Venanzoni, R., Acosta, A.T.R., Agrillo, E., Aleffi, M. et al (2016). A methodological protocol for Annex I Habitats monitoring: the contribution of vegetation science. Plant Sociology, 53, 77-78. https://doi.org/10.7338/pls2016532/06.

Gilbert, M., Pammenter, N., \& Ripley, B. (2008). The growth responses of coastal dune species are determined by nutrient limitation and sand burial. Oecologia, 156, 169-178. https://doi.org/10.1007/s0044 2-008-0968-3.

Grubb, P.J. (1977). The maintenance of species-richness in plant communities: the importance of the regeneration niche. Biological Review, 52, 107-145. https://doi.org/10.1111/j.1469-185X.1977.tb01347.x.

Guja, L.K., Merritt, D.J., \& Dixon, K.W. (2010). Buoyancy, salt tolerance and germination of coastal seeds: implications for oceanic hydrochorous dispersal. Functional Plant Biology, 37, 1175-1186.

Gul, B., Ansari, R., Flowers, T.J., \& Khan, M.A. (2013). Germination strategies of halophyte seeds under salinity. Environmental and Experimental Botany, 92, 4-18. https://doi.org/10.1016/j.envexpbot.2012.11.006.

Hammer, Ø., Harper, D.A.T., \& Ryan, P.D. (2001). PAST: paleontological statistics software package for education and data analysis. Palaeontologia Electronica, 4, 9. http://palaeo-electronica.org.

Hesp, P.A. (1991). Ecological processes and plant adaptations on coastal dunes. Journal of Arid Environments, 21, 165-191.

Hilhorst, H.W.M., \& Karssen, C.M. (2000). Effect of chemical environment on seed germination. In M. Fenner (Ed.), Seeds: the Ecology of Regeneration in Plant Communities (2nd ed). Oxon, UK: CABI Publishing, pp. 293-310.

Huang, X., Schmitt, J., Dorn, L., Griffith, C., Effgen, S., Takao, S. et al (2010). The earliest stages of adaptation in an experimental plant population: 
strong selection on QTLS for seed dormancy. Molecular Ecology, 19, 1335-1351. https://doi.org/10.1111/j.1365-294X.2010.04557.x.

Ibrahim, M.E.H., Zhu, X., Zhou, G., Ali, A.Y.A., Ahmad, I., \& Farah, G.A. (2018). Nitrogen fertilizer alleviated negative impacts of $\mathrm{NaCl}$ on some physiological parameters of wheat. Pakistan Journal of Botany, 50, 2097-2104.

Isermann, M. (2011). Patterns in species diversity during succession of coastal dunes. Journal of Coastal Research, 27, 661-671. https://doi. org/10.2112/JCOASTRES-D-09-00040.1.

Jiménez-Alfaro, B., Silveira, F.A.O., Fidelis, A., Poschlod, P., \& Commander, L.E. (2016). Seed germination traits can contribute better to plant community ecology. Journal of Vegetation Science, 27, 637-645. https://doi.org/10.1111/jvs.12375.

Kachi, N., \& Hirose, T. (1983). Limiting nutrients for plant growth in coastal sand dune soils. Journal of Ecology, 71, 937-944. https:// www.jstor.org/stable/2259603.

Keith, D.A., Rodríguez, J.P., Rodríguez-Clark, K.M., Nicholson, E., Aapala, K., Alonso, A. et al (2013). Scientific Foundations for an IUCN Red List of Ecosystems. PLoS ONE, 8, 1-25. https://doi.org/10.1371/journ al.pone.0062111.

Kooijmann, A.M., \& Besse, M. (2002). The higher availability of $\mathrm{N}$ and $\mathrm{P}$ in lime-poor than in lime-rich coastal dunes in the Netherlands. Journal of Ecology, 90, 394-403. https://doi. org/10.1046/j.1365-2745.2001.00661.x.

Larcher, W. (Ed.) (2003). Physiological Plant Ecology, 4th ed. Berlin: Springer.

Lindgaard, A., \& Henriksen, S. (Eds.) (2011). The 2011 Norvegian Red List for Ecosystems and Habitat Types. Norwegian Biodiversity Information Centre, Trondheim: Artsdatabanken, p. 120.

Martínez, M.L., \& Psuty, M. (Eds.) (2004). Coastal Dunes: Ecology and Conservation. Berlin: Springer-Verlag.

Manzoor, S., Hameed, A., Khan, M.A., \& Gul, B. (2017). Seed germination ecology of a medicinal halophyte Zygophyllum propinquum: responses to abiotic factors. Flora, 233, 163-170. https://doi.org/10.1016/j. flora.2017.06.004.

Maun, M.A. (1994). Adaptations enhancing survival and establishment of seedlings on coastal dune systems. Vegetatio, 111, 59-70. https://doi. org/10.1007/BF00045577.

Maun, M.A. (Ed.) (2009). The Biology of Coastal Sand Dunes. United Kingdom: Oxford University Press.

McLachlan, A., \& Defeo, O. (Eds.) (2017). The Ecology of Sandy Shores, 3rd ed. United Kingdom: Academic Press.

Murru, V., Santo, A., Piazza, C., Hugot, L., \& Bacchetta, G. (2015). Seed germination, salt-stress tolerance, and the effect of nitrate on three Tyrrhenian coastal species of the Silene mollissima aggregate (Caryophyllaceae). Botany-Botanique, 93, 881-892. https://doi. org/10.1139/cjb-2015-0148.

Neid, S.L., \& Biesboer, D.D. (2005). Alleviation of salt-induced stress on seed emergence using soil additives in a greenhouse. Plant and Soil, 268, 303-307. https://doi.org/10.1007/s11104-004-0313-5.

OECD (2006). Test No. 208: Terrestrial Plant Test: Seedling Emergence and Seedling Growth Test, OECD Guidelines for the Testing of Chemicals (Section 2). Paris: OECD Publishing. https://doi.org/10.1787/97892 64070066-en.

Ooi, M., Aulk, T., \& Whelan, R. (2004). Comparison of the cut and tetrazolium tests for assessing seed viability: a study using Australian native Leucopogon species. Ecological Management \& Restoration, 5 , 141-143. https://doi.org/10.1111/j.1442-8903.2004.00201e.x.

Parmesan, C., \& Hanley, M.E. (2015). Plants and climate change: complexities and surprises. Annals of Botany, 116, 849-864. https://doi. org/10.1093/aob/mcv169.

Pinna, M.S., Bacchetta, G., Cogoni, D., \& Fenu, G. (2019). Is vegetation an indicator for evaluating the impact of tourism on the conservation status of Mediterranean coastal dunes? Science of the Total Environment, 674, 255-263. https://doi.org/10.1016/j.scitotenv.2019.04.120.
Pizzo, L. (2012). Analisi dei processi di invasione di piante esotiche nei paesaggi costieri sabbiosi del Veneto. PhD Thesis. http://hdl.handle. net/10579/1204.

Poorter, L. (2007). Are species adapted to their regeneration niche, adult niche, or both? The American Naturalist, 169, 433-442. https://doi. org/0003-0147/2007/16904-41565\$15.00.

Pons, T.L. (1989). Breaking of seed dormancy by nitrate as a gap detection mechanism. Annals of Botany, 63, 139-143. https://doi.org/10.1093/ oxfordjournals.aob.a087716.

Poschlod, P., Abedi, M., Bartelheimer, M., Drobnik, J., Rosbakh, S., \& Saatkamp, A. (2013). Seed ecology and assembly rules in plant communities. In E. van der Maarel (Ed.), Vegetation Ecology. Chichester, UK: Wiley-Blackwell, pp. 164-202.

Rajaniemi, T.K., \& Barrett, D.T. (2018). Germination responses to abiotic stress shape species distributions on coastal dunes. Plant Ecology, 219, 1271-1282. https://doi.org/10.1007/s11258-018-0877-4.

Rivas-Martínez, S., Penas, A., \& Díaz, T.E. (2004). Bioclimatic Map of Europe, Bioclimates, Cartographic Service. Spain: University of León. https://webs.ucm.es/info/cif/index.html.

Royal Botanic Gardens Kew (2008). Seed Information Database (SID). Version 7.1. Retrieved from http://data.kew.org/sid/.

Ruocco, M., Bertoni, D., Sarti, G., \& Ciccarelli, D. (2014). Mediterranean coastal dune systems: which abiotic factors have the most influence on plant communities? Estuarine Coastal and Shelf Science, 149, 113122. https://doi.org/10.1016/j.ecss.2014.08.019.

Saatkamp, A., Cochrane, A., Commander, L., Guja, L.K., Jiménez-Alfaro, B., Larson, J. et al (2019). A research agenda for seed-trait functional ecology. New Phytologist, 221, 1764-1775. https://doi.org/10.1111/ nph.15502.

Saeed, S., Gul, B., \& Khan, M.A. (2011). Comparative effects of $\mathrm{NaCl}$ and sea salt on seed germination of Arthrocnemum indicum. Pakistan Journal of Botany, 43, 1091-1103.

Santo, A., Mattana, E., Hugot, L., Spinosi, P., \& Bacchetta, G. (2014). Seed germination and survival of the endangered psammophilous Rouya polygama (Apiaceae) in different light, temperature and $\mathrm{NaCl}$ conditions. Seed Science Research, 24, 331-339. https://doi.org/10.1017/ s0960258514000282.

Santo, A., Mattana, E., Frigau, L., Marzo Pastor, A., Picher Morelló, M.C., \& Bacchetta, G. (2017). Effects of $\mathrm{NaCl}$ stress on seed germination and seedling development of Brassica insularis Moris (Brassicaceae). Plant Biology, 19, 368-376.

Santo, A., Dessì, L., Ucchesu, M., Bou Dagher Kharrat, M., Sakr, R.C., Accogli, R.A. ... et al (2019). Seed germination ecology and salt stress response in eight Mediterranean populations of Sarcopoterium spinosum (L.) Spach. Plant Species Biology, 34, 110-121.

Silan, G., Del Vecchio, S., Fantinato, E., \& Buffa, G. (2017). Habitat quality assessment through a multifaceted approach: the case of the habitat 2130* in Italy. Plant Sociology, 54, 13-22. https://doi.org/10.7338/ pls2017542/02.

Slaviero, A., Del Vecchio, S., Pierce, S., Fantinato, E., \& Buffa, G. (2016). Plant community attributes affect dry grassland orchid establishment. Plant Ecology, 217, 1533-1543. https://doi.org/10.1007/s1125 8-016-0666-x.

Torca, M., Campos, J.A., \& Herrera, M. (2019). Changes in plant diversity patterns along dune zonation in south Atlantic European coasts. Estuarine Coastal and Shelf Science, 218, 39-47. https://doi. org/10.1016/j.ecss.2018.11.016.

USDA (2014). Soil Quality Indicators. Available at https://www.nrcs.usda. gov/wps/portal/nrcs/detail/soils/health/assessment/?cid=stelp rdb1237123.

van Puijenbroek, M.E.B., Teichmann, C., Meijdam, N., Oliveras, I., Berendse, F., \& Limpens, J. (2017). Does salt stress constrain spatial distribution of dune building grasses Ammophila arenaria and Elytrichia juncea on the beach? Ecology and Evolution, 7, 7290-7303. https://doi.org/10.1002/ece3.3244. 
Yuan, F., Guo, J.R., Shabala, S., \& Wang, B.S. (2019). Reproductive physiology of halophytes: Current standing. Frontiers in Plant Science, 9, 13. https://doi.org/10.3389/fpls.2018.01954.

Walck, J., Hydayati, S., Dixon, K., Thompson, K., \& Poschlod, P. (2011). Climatechangeandplantregenerationfromseed.GlobalChangeBiology, 17, 2145-2161. https://doi.org/10.1111/j.1365-2486.2010.02368.x.

Zehra, A., Gul, B., Ansari, R., Alatar, A.R.A., Hegazy, A.K., \& Khan, M.A. (2013). Action of plant growth regulators in alleviating salinity and temperature effects on the germination of Phragmites karka. Pakistan Journal of Botany, 45, 1919-1924.

Zheng, Y.H., Jia, A.J., Ning, T.Y., Xu, J.L., Li, Z.J., \& Jiang, G.M. (2008). Potassium nitrate application alleviates sodium chloride stress in winter wheat cultivars differing in salt tolerance. Journal of
Plant Physiology, 165, 1455-1465. https://doi.org/10.1016/j. jplph.2008.01.001.

How to cite this article: Del Vecchio S, Fantinato E, Roscini M, Acosta ATR, Bacchetta G, Buffa G. The germination niche of coastal dune species as related to their occurrence along a sea-inland gradient. J Veg Sci. 2020;31:1114-1123. https://doi. org/10.1111/jvs.12899 